Uniwersytet im. Adama Mickiewicza w Poznaniu

\title{
Konteksty oraz uwarunkowania ruchu separa- tystycznego we wschodnim regionie Ukrainy w 2014 roku
}

OELEM ARTYKUŁU JEST PRÓBA OKREŚlENIA PRZYCZYN SEPARATYZMU WE wschodnim regionie Ukrainy w 2014 r. Przyczyny te tkwią w różnych płaszczyznach, z których każda ma swoje określone podstawy. Zostały one osobno opisane oraz zweryfikowano ich wpływ na rozwój ruchu separatystycznego na Ukrainie, w oparciu o metodę historyczną (w tym genetyczną), behawioralną oraz decyzyjną.

Hasłowo został opisany przebieg wydarzeń, które doprowadziły do konfliktu zbrojnego w Donieckim Zagłębiu Węglowym¹, do niezapowiedzianej wojny o charakterze hybrydowym, a także do zjawiska uchodźstwa wewnętrznego. Zjawiska, z którym Ukraina nie miała do czynienia od czasów drugiej wojny światowej.

Hipoteza naukowa, która figuruje w artykule, ma następującą formę - podział w wymienionych w artykule podłożach secesji występuje pomiędzy regionami Ukrainy, gdzie ruchy separatystyczne są rozpowszechnione a regionami, w których ruchom separatystycznym udało się zapobiec, czy jednak podział ten jest sztuczny.

W artykule zostały opisane definicje separatyzmu oraz wojny hybrydowej, wykorzystane zostały badania autorów krajowych oraz zagranicznych. Wykorzystano materiał z ukraińskich źródeł.

\section{DEFINICJA SEPARATYZMU}

WedŁug MaŁego SŁownika Politologit pod redakcją Stefana Opary (2007) pojęcie separatyzmu oznacza „dążenie do oderwania się części terytorium od państwa w celu stworzenia nowego odrębnego organizmu państwowego, przyłączenia tego terytorium do sąsiedniego kraju lub otrzymania statusu autonomii” (s. 149). Także w słowniku zaznaczono, że separatyzm może być przyczyną „naruszenia suwerenności i jednolitości terytorialnej państwa oraz zasad nienaruszalności gra-

${ }^{1}$ Dalej jest wykorzystywany skrót Donbas. 
nic, a także - jak pokazuje praktyka - może być źródłem konfliktów międzynarodowych”.

Równorzędna pojęciu separatyzmu jest definicja secesji - „pojęcie z zakresu prawa międzynarodowego, oznaczające odłączenie od terytorium państwa jego części [...]” (Mały Słownik Polityki, 1998).

Encyklopedia Wiedzy Politycznej (2005) podaje nastepujące pojęcie secesji - „dążenie jakieś regionu w określonym systemie politycznym do niezależności od reszty państwa i możliwości decydowania o sobie na zasadzie autonomii”.

Jak zaznacza Anna Antczak-Barzan (2016) „separatyzm umożliwia ukierunkowanie i pewną formę „zmaterializowania” niezadowolenia części społeczeńtwa z obecnej sytuacji w taki sposób, że osiągnięcie kompromisu staje się praktycznie niemozliwe, gdyż nie ma żadnych punktów wspólnych, na których można by zacząć budować porozumienie" (s. 33).

Zazwyczaj proces separatyzmu występuje w państwach wielonarodowych, w których pragnienia określonej mniejszości narodowej do oddzielenia się oraz utworzenia niepodległego państwa stają się głównym celem i są osiągalne przy pomocy różnych instrumentów od pokojowego referendum (np. separatyzm w Szkocji, w kraju Basków, etc.) do konfliktu zbrojnego (Ukraina, Kosowo, Kurdystan, etc.). $\mathrm{W}$ wielu przypadkach przyczyną separatyzmu w życiu politycznym kraju jest podział kulturowy, etniczny lub religijny. Również przyczyną podobnych ruchów mogą być sztuczne granice, które nie zostały stworzone z woli mieszkańców tego państwa. Stąd często wynika dążenie niektórych grup społecznych do rewizji wcześniej ustalonych granic.

Separatystyczny ruch rozróżnia się według przebiegu w krajach rozwiniętych i państwach rozwijających się. Prawie zawsze większość strajkujących w krajach rozwijających się pochodzi z niższych warstw społecznych. Przyczyną niezadowoleń jest zazwyczaj nieproduktywny rozwój gospodarczy konkretnego regionu. W większości przypadków w takich państwach ruchy separatystyczne tłumi się za pośrednictwem policji lub wojska. W wypadku separatyzmu we wschodnim regionie Ukrainy oraz w szczególności w Donbasie jest to nie tylko nieskuteczny rozwój gospodarczy ostatnich dekad, lecz także szereg innych przyczyn, z których każda posiada swoje własne podłoże.

Natomiast w państwach rozwiniętych nastroje społeczności pragnącej oddzielenia się są mniej ekstremistyczne, zwykle są wyrażone dążeniami do szerokiej autonomii. Często takie ruchy przybierają 
kształt partii politycznej. Ogranicza lub normalizuje taki ruch separatystyczny przede wszystkim pokojowo, drogą ogólnopaństwowych debat politycznych. Przykładem mogą służyć ruchy separatystyczne w Szkocji lub prowincji Quebec w Kanadzie.

Przykład ukraińskiego separatyzmu na Donbasie oraz Krymie jest wieloaspektowy. Wyrósł z procesów politycznych wśród ukraińskich partii i był kontynuowany jako wojna hybrydowa.

\section{SEPARATYZM NA UKRAINIE JAKO ELEMENT WROGIEJ TAKTYKI}

OD UZYSKANIA NIEPODLEGŁOŚCI W 1991 R. UKRAINA NIERAZ SPOTKAŁA SIĘ ze zjawiskiem separatyzmu. Jeszcze w latach 90. w referendum 80\% mieszkańców Donbasu zagłosowało za federalizcję (Український Тиждень, 2016), jednak wtedy podobne dążenia nie rozwinęły się w idee separatyzmu. 26 listopada 2004 r. Sesja Rady Regionalnej w Ługańsku postanowiła utworzyć autonomię dla Południowo-Wschodniej Ukrainy (Луганский Областной Совет, 2004). Posłowie ogłosili zamknięcie granic obwodu Ługańskiego oraz zaapelowali do Federacji Rosyjskiej o pomoc. W tym samym dniu w Odessie wśród niektórych sił politycznych został wysunięty wymóg o utworzeniu tak zwanego „Państwa Noworosyjskiego” albo „Noworosji”. Trzeba zauważyć, że temat „Noworosji” jest zbyt szeroki, żeby jego ujmować w jednym artykule. Warto jedynie zaznaczyć, że projekt stworzenia nowego państwa na południowym wschodzie Ukrainy nie jest nowym. Nie był on stworzony podczas protestów na Majdanie w Kijowie jako „Antymajdan”, lecz był racjonalnie zaplanowany i pochodził spoza Ukrainy.

27 listopada 2004 r. w Charkowie urzędnicy skoncentrowali władze w rękach gubernatora, który został obciążony obowiązkami koordynacji działań w obwodzie Charkowskim. Obowiązki gubernatora teoretycznie musiały należeć do sterowania „Państwem Noworosyjskim”, czyli obwodami Dniepropietrowskim, Odeskim, Mikołajewskim, Chersońskim, Zaporoskim, Donieckim, Charkowskim oraz Ługańskim.

28 listopada 2004 r. w mieście Siewierodonieck (obwód Ługański) został ogłoszony projekt stworzenia Ukraińskiej Południowo-Wschodniej Republiki Autonomicznej. Jednak ten pomysł nie został rozpowszechniony na większą skalę i przestał istnieć na początku $2005 \mathrm{r}$. Ruch separatystyczny na Ukrainie w 2014 r. posiada tylko podobne podstawy, lecz różni się zasadniczo charakter jego rozwoju, który zbliża się do permanentnej wojny z elementami wojny domowej i licznymi 
atakami terrorystycznymi, które nie gasną podczas pisania niniejszego artykułu.

Ruch separatystyczny na Ukrainie w 2014 r. powstał najpierw na Krymie, potem w południowo-wschodnim regionie, w tym w Donbasie w celu odłączenia części terytorium Ukrainy, tuż po wydarzeniach na Euromajdanie. Istotne znaczenie miał także czynnik wewnętrzny w postaci różnic terytorialnych wewnątrz Ukrainy (domniemany konflikt Wschodu i Zachodu Ukrainy, ukraińskojęzycznych z rosyjskojęzycznymi, etc.). Procesy separatystyczne w Donbasie już w kwietniu 2014 r. przyciągnęły najemników z Czeczeni oraz Osetii, Dońskich Kozaków, najemników z Serbii oraz inne organizacje paramilitarne. Po ogłoszeniu przez nowy ukraiński rząd 13 kwietnia 2014 r. rozpoczęcia antyterrorystycznej operacji ${ }^{2} \mathrm{w}$ Donbasie zaczęły się starcia wojenne z użyciem lotnictwa, ciężkiej artylerii oraz czołgów (Українська Правда, 2014). Wkrótce działania wojenne w Donbasie stały się przyczyną olbrzymiej fali migracji wewnętrznej.

Region, w którym wiosną 2014 r. zrodził się ruch separatystyczny w skrócie jest nazywany Donbas (Doniecki Basen) albo Donieckie Zagłębie Węglowe. Donbas położony jest głównie w dwóch obwodach administracyjnych - Donieckim oraz Ługańskim (także w części obwodu Dniepropietrowskiego oraz obwodu Rostowskiego Rosji). Nazwę „Doniecki Basen” sformułował w 1829 r. Jewgraf Kowalewski inżynier-geolog z Charkowa, który przeprowadził pierwsze naukowe badania stratygraficzne i geologiczne z zagłębia węglowego i stworzył pierwszą mapę występowania pokładów węgla w tym regionie (Marta Studenna-Skrukwa, 2014, s. 9). Geograficznie Donbas jest najbardziej wysuniętym na wschód regionem współczesnej Ukrainy. „Zarówno na Ukrainie, jak i poza nią, pole semantyczne samego określenia Donbas rozszerza się na pewną odrębną przestrzeń kulturową, która charakteryzuje nie tyle część Ukrainy, ile ukraińsko-rosyjskie pogranicze” (Studenna-Skrukwa, 2014, s. 9).

Podłoża ruchu separatystycznego na Ukrainie w 2014 r. są różnorakie. Mianowicie, są to podstawy gospodarcze, światopoglądowe, historyczne, geopolityczne, społeczne, językowe, etniczne oraz cywilizacyjne.

\section{PODŁOŻE HISTORYCZNE}

${ }^{2}$ Powszechnie jest używany skrót ATO. 
HistoryCZNIE REGION DONBASU BYŁ CZĘŚCIĄ UKRAIŃSKIEGO POLA ETNICZNEGO. Naturalnie naród ukraiński przeprowadził główną kolonizację tego regionu, który w przeszłości był nazywany Dzikie Pole. Jest to także staropolska nazwa obecnego regionu Zaporoża. Była to kraina historyczna w okresie od XV do XVIII w., położona nad dolnym Dnieprem, na południe od zamku Kudak, poniżej tzw. progów, w ówczesnym województwie kijowskim, na wschód od rzeki Dniestr. Granice Dzikich Pól na wschodzie i południu wyznaczały rzeka Don i wybrzeża Morza Czarnego z zamkiem Oczaków.

Z początkiem rozwoju przemysłowego, do Donbasu masowo przybywali obywatele z całego Imperium Rosyjskiego. Jednak niewielka zmiana składu etnicznego Donbasu nie przyczyniła się do rozwoju ruchów separatystycznych w nim. Wyjątkiem jest utworzenie w 1918 r. Doniecko-Krzyworoskiej Republiki, która przetrwała jeden miesiąc. $\mathrm{Z}$ tego powodu władze Rosyjskiej Federacji nie mają podstaw twierdzić, że Donbas ewentualnie może występować jako jej integralna część, w przeciwieństwie do Krymu, który został anektowany 21 marca 2014 r. (Президент России, 2014).

\section{PodŁoże ŚWIATOPOGLĄDOWE}

ŚWIATOPOGLĄD, KTÓRY DOMINOWAŁ NA TERENIE ZAGŁĘBIA DONIECKIEGO W CIĄGu ostatnich dwóch dekad po pierwsze wyróżniał się poparciem większości wyborców dla Komunistycznej Partii Ukrainy³. Po drugie, ten światopogląd cechował się niemal jednogłośnym uznaniem dla Partii Regionów, co z kolei zapewniło dominację byłych radzieckich politycznych działaczy partyjnych, ale z silną obecnością nowych elementów przestępczych. Podobna kryminalno-polityczna symbioza wykreowała nową rzeczywistość w regionie Zagłębia Donieckiego, która w większości przypadków w ciągu ostatnich dwudziestu lat nie podlegała jurysdykcji Kijowa.

Dominacja jednej partii w Donbasie była inspirowana także ogólnym wizerunkiem społecznym. Jak zaznacza Marta Studenna-Skrukwa: „w ogólnoukraińskiej percepcji po 1991 roku Donbas wyraźnie uosabia centrum patalogii społecznych: przestępczości [...], korupcji, alkoholizmu, agresji i chamstwa. Mieszkańcom Donbasu imputuje się

${ }^{3}$ Obecnie nie występuje w Parlamencie Ukraińskim. W 2014 r. zaczął się proces sądowy likwidacji partii (Президент України. Офіційне інтернет-представництво, 2014). 
także ogólny brak ogłady, ignorancję oraz niechęć do obcowania z kulturą wysoką" (Studenna-Skrukwa, 2014, s. 218).

Wyżej wymieniony światopogląd hasłowo można określić następującymi postulatami, wykorzystywane przez separatystów są:

- odrzucenie narodowej (ukraińskiej) tożsamości. Spora część lokalnego społeczeństwa identyfikuje się z ludem radzieckim, który po upadku Związku Radzieckiego pozostał w różnych państwach. Warto przytoczyć dla przykładu powszechnie wznane powiedzenie - cytat z piosenki z początku lat 70 . $\mathrm{XX}$ w., rozpowszechnione w państwach postradzieckich, które najlepiej tłumaczy istotę ludu radzieckiego „Mój adres nie dom i nie ulica, mój adres - Związek Radziecki”;

- ignorowanie języka państwowego (ukraińskiego). Podobnie jak w przypadku pierwszego postulatu, wielu mieszkańców donieckiego regionu identyfikuje się z ludem radzieckim oraz rozmawia w języku komunikacji międzynarodowej ZSRR - czyli w języku rosyjskim. Należy również zauważyć, że w ciągu ostatnich dwudziestu lat niepodległości Ukrainy Donbas był w dużej mierze w przestrzeni informacyjnej Rosji;

- dominacja postradzieckiego materialistycznego światopoglądu, który nie generował krytycznej samooceny jednostki;

- zniekształcone oraz niepełne wyobrażenie narodowej historii Ukrainy, co spowodowało brak tożsamości narodowej, pozostawiając społeczność Donbasu przywiązaną do historii ww. ludu radzieckiego;

- gloryfikacja socjalistycznego modelu organizacji gospodarki, który stał się reliktem przeszłości; negatywne postrzeganie prywatnej własności a pozytywny odbiór programów socjalnych dla społeczeństwa ze względu na wysokie opodatkowanie podmiotów prywatnych;

- $\quad$ brak tradycji demokratycznych oraz samorządowych, niezdolność do samoorganizacji społeczeństwa i udziału w samorządzie lokalnym.

\section{PoDŁOŻE GOSPODARCZE}

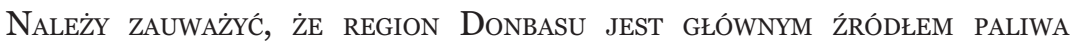
ORAZ energii dla centralnych i południowych regionów Ukrainy (Dniepropietrowsk, Donieck, Zaporoże oraz Ługańsk) i Rosji (Rostów). Jednakże, w ramach gospodarczego podziału na strefy ekonomiczne 
w ramach ZSRR, Donbas nie był powiązany z obwodem Rostowskim Federacji Rosyjskiej, co udowodnia struktura rejonów gospodarczych, które istniały przed $1991 \mathrm{r}$. W czasach ZSRR Donbas należał do Doniecko-Przydnieprowskiego regionu gospodarczego, który był w obrębie USRR.

\section{PodŁOŻe ETNICZNE}

WRAZ Z ROSNĄCĄ POPULACJA MIEJSKĄ, W XX WIEKU, ZMIENIAŁ SIĘ SKŁAD ETNICZNY ludności i miast Donbasu. Na początku lat 20. ubiegłego wieku ludność ukraińska stanowiła większość - 64\% całej populacji, natomiast ludność rosyjska stanowiła 26\% ogólnej populacji (Валерій Смолій, 2012, s. 103). W okresie lat 1920-1930 miał miejsce szybki wzrost liczebności populacji pochodzącej z Rosji, ponieważ wtedy Donbas był jednym z najbardziej atrakcyjnych regioneów dla migracji ludności wiejskiej z całego ZSRR (Смолій, 2012, s. 103). W ciągu trzynastu lat, od 1926 r. do 1939 r. liczba Rosjan w Donbasie wzrosła o 105\%, podczas gdy liczba Ukraińców о 60\% (В. Смолій, 2012, s. 103). W konsekwencji zmienił się ilościowy stosunek Rosjan oraz Ukraińców w strukturze etnicznej Donbasu.

Jak zaznacza M. Studenna-Skrukwa: „w skali całej Ukrainy Rosjanie przeważali wśród pracowników umysłowych w grupie specjalistów technicznych. W 1926 roku stanowili 34 procent zatrudnionych w administracji i 43 procent w przemyśle. Do najważniejszych kategorii pracowników należeli inżynierowie, których rola ogromnie wzrosła za Stalina” (Studenna-Skrukwa, 2014, s. 148). Także: „[...] w latach 1946-1950 z Rosji, Białorusi i Mołdawii do obwodu donieckiego skierowano 246 tys. robotników. [...] Szeroko wykorzystywana była praca tzw. batalionów robotniczych, sformowanych z jeńców wojennych, osób internowanych, więźniów oraz repatriantów" (Studenna-Skrukwa, 2014, s. 153).

Istotnym elementem formowania etnicznego przekroju Donbasu były procesy, które zaszły po Wielkim Głodzie na Ukrainie w latach 1932-1933 (BBC, 2015). Według dokumentów archiwalnych po Wielkim Głodzie na obszary „wyzwolone” od lokalnej ukraińskiej ludności do ówczesnego obwodu Donieckiego (w tym ówczesny obwód Ługański), Dniepropietrowskiego (do którego częściowo należał dzisiejszy obwód Zaporoski) oraz obwodu Charkowskiego zostali przesiedleni rolnicy z Rosji. Do obwodu Odeskiego (wtedy rozprzestrzeniał się na terytorium obwodów Mikołajowskiego oraz Chersońskiego) zostali przesiedleni rolnicy z Białorusi i Rosji. Pod koniec 1933 r. z za- 
chodnich regionów Rosji do Dniepropietrowskiego regionu wysłano 109 pociągów osadników, do Charkowskiego regionu - 80 pociągów, do Donieckiego regionu - 44 pociągów (BBC, 2015).

Jeśli porównać na mapie terytoria, które separatyści w 2014 r. mianowali „Noworosją” oraz terytoria przesiedleń w latach po Wielkim Głodzie, to można zauważyć precyzyjne zbieżności (BBC, 2015).

Podobne procesy w przeszłości mogły w znacznej mierze przyczynić się do dużych zmian składu etnicznego dzisiejszego Donbasu. Taki skład etniczny z kolei mógł w pewnej mierze wpłynąć na procesy separatystyczne $\mathrm{w}$ regionie.

\section{PoDŁOŻE SPOŁECZNE}

DominuJĄCYMi DZIEDZINAMi PRZEMYSŁu w DONBASIE SĄ HUTNICTWO, GÓRnicTwo, inżynieria chemiczna oraz mechaniczna. Przemysły te charakteryzują się wyjątkowo wysokim poziomem obrażeń. Pod względem ryzyka wybuchu gazu i pyłu, węgla i pożarów gazowych Donbas jest jednym z najbardziej niebezpiecznych miejsc pracy na świecie. Liczba wypadków śmiertelnych w kopalniach rocznie wynosi od 250 do 350 (Workingman's death, 2005). Zanieczyszczenie środowiska przekracza znacznie dopuszczalne wskaźniki. Sytuacje stresowe w takich okolicznościach budują świat mentalny mieszkańców Donbasu. Osobowość ludzka permanentnie ulega zmianom, wartości światopoglądowe stają się uproszczone, pozostawiając tylko podstawowe - instynkt samozachowawczy, zaopatrzenie materialne oraz prokreacja. Partia rządząca (najpierw Partia Komunistyczna Ukrainy, a potem Partia Regionów) kreowały przez dziesięciolecia pseudo-wartości - jedne gloryfikując, inne natomiast tłumiąc. Przykładem takich działań były ruch stachanowski, wyścig socjalistyczny, dynastie robotnicze etc. W podobnych okolicznościach jednostka w szczególności, a społeczeństwo w ogóle stają się kosmopolitycznymi, następuje zanik więzi kulturowych lub politycznych, nieważne stają się idea narodowa, język ojczysty, historia, etc. Natura jednostki ludzkiej w takich okolicznościach staje się relatywnie bezwzględną, język uproszczony i slangowy, ale gotowość do ochrony podstawowych wartości wzrasta. Podstawą takiego sądu jest pojęcie dewiacji społecznej - przejaw pewnego odchylenia od ustalonych zasad i reguł społecznych. W dziedzinie swoich podstawowych wartości na takie jednostki jest bardzo łatwo wywierać wpływ drogą administracyjną. Przykładem szerokiego wykorzystania środków administracyjnych były wybory prezydenckie na Ukrainie w $2010 \mathrm{r}$. 


\section{PoDŁOŻE JĘZYKOWE}

OGÓLNIE, JĘZYK JEST POTĘŻNYM NARZĘDZIEM KONSOLIDACYJNYM, JEDNAK w ostatnich latach niepodległości Ukrainy język ukraiński w Donbasie stał się czynnikiem wielkich napięć. Na Ukrainie istnieje kilka regionów językowych oraz kulturowych (jest to zjawisko naturalne dla każdego wielkiego państwa). Głównie ukraińskojęzyczny jest Zachód (obwody Wołyński Rówieński, Chmielnicki, Lwowski, Iwano-Frankowski, Tarnopolski, Zakarpacki oraz Czerniowiecki), natomiast rosyjskojęzyczny pozostaje Wschód (obwody Charkowski, Doniecki oraz Ługański) i Południe (obwody Odeski, Mikołajewski, Chersoński, Zaporoski oraz Republika Krymu). Centrum z kolei jest dwujęzyczne (obwody Żytomierski, Winnicki, Kirowohradzki, Charkowski, Kijowski, Dniepropietrowski, Połtawski, Sumski oraz Czernihowski). Warto dodać, że wykorzystanie oraz rozpowszechnianie języka ukraińskiego od 1990 r. maleje w całej Ukrainie, co z kolei zmniejsza możliwości integracyjne języka.

\section{PodŁOŻE GEOPOLITYCZNE}

Pod WZGLĘDEM GEOPOLITYCZNYM PRZEZ DoNBAS PRZEBIEGAJĄ LĄDOWE POŁĄCZENIA Rosji z półwyspem Krymskim - droga lądowa z Rostowa nad Donem przez Mariupol, Melitopol do Sewastopola. Także przez Donbas przebiega droga lądowa łącząca Naddniestrze z Rosją - z RRostowa nad Donem przez Mariupol, Melitopol, Chersoń, Odessę do Tyraspolu. Teoretycznie, w razie przejęcia obwodu Zaporoskiego przez separatystów Federacja Rosyjska otrzymałaby dostęp lądowy do półwyspu Krymskiego. W takim razie nie istniałaby potrzeba budowy mostu nad Cieśniną Kerczeńską (Rynek Kolejowy, 2016).

\section{PodŁOŻe CYWILIZACYJNe}

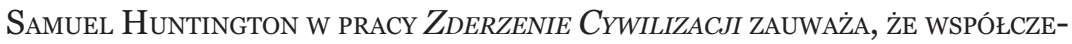
SNY świat można podzielić na 9 głównych cywilizacji (Samuel Huntington, 2002, s. 27), które zdecydowanie różnią się od siebie. Wszelkie konflikty (w tym ruchy secesyjne), które występują w świecie, według autora ww. pracy, zachodzą na granicach cywilizacji. Można tylko przypuszczać, że ruch separatystyczny w Donbasie wiosną 2014 r. jest przyczyną zderzenia dwóch wyraźnie różnych cywilizacji. Aczkolwiek tak Ukraina, jak i Rosja według Huntingtona należą do jednej cywilizacji Prawosławnej (Orthodox). 
Huntington zauważa także, że w nowym świecie źródłem głównych konfliktów nie będzie ani ideologia polityczna, ani ekonomia. Zasadnicze granice, które będą dzielić ludzkość oraz dominujące źródła konfliktów zostaną ustalone przez kulturę. Narodowe państwa pozostaną głównym obiektem stosunków międzynarodowych, ale najbardziej znaczące konflikty polityki globalnej będą rozwijać się pomiędzy narodami i grupami należącymi do różnych cywilizacji. Zderzenie cywilizacji będzie dominującym faktem polityki światowej. Linia dzieląca cywilizacje stanie się w przyszłości linią frontu (S. Huntington, 2002, s. 33).

Obecnie można tylko przypuszczać, że konflikt zbrojny we wschodniej Ukrainie, który rozpoczął się w kwietniu 2014 r. pomiędzy separatystami i ukraińskim wojskiem, jest konfliktem pomiędzy dwiema cywilizacjami. Rozgrywa się on pomiędzy dwiema diametralnie różnymi kulturami i światopoglądami. Ukraińska armia broni idei nowej Ukrainy, społeczeństwa, które nie chce się włączyć ani do radzieckiej spuścizny Rosji, ani do systemu oligarchicznego, który wzmocnił się podczas rządów Wiktora Janukowycza. Natomiast separatyści w Donbasie bronią idei powrotu do wartości sowiecko-rosyjskich w gospodarce, społeczeństwie oraz polityce (Дзеркало Тижня, 2014).

TŁo POLITYCZNE RUCHU SEPARATYSTYCZNEGO NA UKRAINIE W 2014 ROKU

Po ucieczCe PREZydenta WikTora JanukowycZa 22 Lutego 2014 R., lokalne elity Donbasu, które w większości były przedstawicielami Partii Regionów, zostały zdezorientowane bez partyjnego lidera. Ich sytuacja okazała się niepewna, ponieważ jeszcze przed ucieczką Wiktora Janukowicza, wspierali oni jego reżim, który natychmiast został zazastąpiony nową władzą. Pierwsze oficjalne oświadczenie posła Partii Regionów Oleksandra Jefremowa oddzieliło środowisko polityczne partii od Janukowycza tuż po gwałtownym przeformatowaniu Parlamentu Ukrainy w lutym 2014 r. po wydarzeniach na Euromajdanie (Liga.net, 2016). Michaił Dobkin oraz Giennadij Kernes - gubernator obwodu Charkowskiego oraz prezydent Charkowa, utworzyli „Front Ukraiński” - tak zwaną walkę wyzwoleńczą przeciwko nowej władzy, która według nich drogą nielegalną zajęła budynki administracyjne w Kijowie. Walka Dobkina oraz Kernesa została wkrótce po wielokrotnych odwiedzinach prokuratury generalnej Ukrainy. Wtedy, wśród wydarzeń, które zachodziły w lutym oraz marcu 2014 r. Dobkin oraz Kernes rozpoczeli nową działalność - Dobkin został protegowanym PR $\mathrm{w}$ wyborach prezydenckich, najpierw popierając idee federalizacji, 
a potem kreując nowe hasło „Jeden kraj” (ukr. Єдина Країна). Kernes najpierw gra po stronie separatystów w Charkowie, a potem zajmuje neutralne stanowisko by następnie stać się oficjalnym delegatem Kijowa w Charkowie, stabilizując w miarę możliwości sytuację w regionie. Trzeci - znaczny, ale bez stosunku do ww. figur - Oleg Cariow - zajmował wyraźnie prorosyjską i antyukraińską pozycję. W przeciwieństwie do 2004 r., kiedy odbyła się Pomarańczowa Rewolucja, podczas gdy rządzący Partią Regionów opuścili Ukrainę, niektórzy oficjele nie opuszczali państwa lub robili to tylko chwilowo. Natomiast Cariow permanentnie odwiedzał Moskwę a później zajął pozycje szefa ruchu separatystycznego, zapowiadając utworzenie tak zwanej "Noworosji" (Unian, 2014).

PrzycZyNy oRAZ gŁóWNe PRZESŁanki RUChu SECESJONISTYCZNEGo w DONBASIE RUCH SEPARATYSTYCZNY NA WSCHODZIE UKRAINY I W SZCZEGÓLNOŚCI W DONBASIE należy odróżnić od prorosyjskich ruchów federalistycznych, autonomistycznych oraz innych. Chociaż, tak jak w przypadku Euromajdanu w Kijowie, mogą one posiadać na pierwszy rzut oka wspólne motywy oraz przyczyny:

- nostalgia społeczeństwa za czasami ZSRR, pragnienie silnego i paternalistycznego państwa;

- $\quad$ rosyjska propaganda z jednej strony oraz technologie polityczne niektórych ukraińskich polityków w celu zdobycia jak największego poparcia w społeczeństwie z drugiej;

- $\quad$ sztucznie wytworzony strach przed wartościami państw Zachodnich - zwłaszcza przed USA oraz Unią Europejską;

- podzielony ukraiński elektorat oraz opozycja niektórych politycznych sił do nowego rządu po Euromajdanie;

- $\quad$ silne więzi na poziomie rodzinnym Ukrainy z Rosją, więzi gospodarcze zaczynając od gospodarstw domowych do dużych konglomeratów przemysłowych, które zostały utworzone w jednym całokształcie gospodarczym ZSRR, na przykład takich jak Piwdenmasz w Dniepropietrowsku, Motor Sicz w Zaporożu lub Zakład Lotniczy Antonow w Kijowie oraz wiele innych;

- negatywne stanowisko Rosji wobec europejskich i euroatlantyckich dążeń integracyjnych Ukrainy;

- jeśli na wczesnym etapie wystąpień (luty-marzec 2014 r.) separatyści domagali się szerokiej autonomii dla regionów południowo-wschodniej Ukrainy, to później (od kwietnia 2014 r.) 
ich żądania skoncentrowały się głównie na jednej rzeczy - pełnym oddzieleniu się od jurysdykcji Kijowa, stworzeniu samoistnego państwa oraz wejściu na prawach odrębnego obwodu w skład Federacji Rosyjskiej.

\section{WoJNA HYBRYDOWA w Donbasie}

Pruski teoretyk wojny Carl von Clausewitz, omiJając zaWiŁe DefiniCJE stosowane przez publicystów, stwierdzał, że wojna sensu stricto „nie jest niczym innym jak rozszerzonym pojedynkiem”, także „wojna jest [...] aktem przemocy, mającym na celu zmuszenie przeciwnika do spełnienia naszej woli" (Clausewitz, 1958, s. 15).

Anna Antczak-Barzan twierdzi, że "nowa" wojna jest konfliktem niskiej intensywności, asymetrycznym, wywołanym najczęściej przez prawdziwe, urojone bądź inspirowane nacjonalizmy, konflikty etniczne, religijne, kulturowe (Antczak-Barzan, 2016, s. 20). W przypadku Ukrainy do tej definicji można dodać separatyzm. Zmieniły także się cele wojny. Jeśli wcześniej głównym celem było podporządkowanie terytorium oraz ludności, to obecnie głównym zdaniem jest „zniszczenie celów o charakterze newralgicznym i strategicznym dla pańtwa”, „dlatego „nowe” wojny często mają charakter lokalny, prowadzone przez aktorów niepaństwowych, ale sterowane przez mocarstwa [...]” (Antczak-Barzan, 2016, s. 20). Cele nowych wojen stają się „mniej konkretne, mające często prowadzić do osiągania długofalowych celów albo też stanowić odpowiedź na postępowanie danego podmiotu, wskazać mu ,jego miejsce”. Często cele wojny są skomplikowane, mało wyraziste i prowadzą do długich negocjacji już po ustaniu interwencji o charakterze zbrojnym [...]" (Antczak-Barzan, 2016, s. 21). Konflikt na Ukrainie można opisać przy pomocy wyżej przedstawionych definicji - mieści on tak zagarnięcie części terytorium, jak i próbę wpływu na decyzje ukraińskiego rządu.

Oficjalnie, działania wojenne prowadzone przez rząd ukraiński z separatystami od kwietnia 2014 r. nazywane są operacją antyterrorystyczną. Nieoficjalnie, działania wojenne w Donbasie określane są Wojną na wschodzie Ukrainy, gdzie przeciwnik nie jest klarownie określony (nie jest to konkretna organizacja, armia lub grupa polityków). Z definicji wojna przewiduje istnienie co najmniej dwóch stron konfliktu, natomiast w Donbasie nie da się w pełni określić przeciwnika ukraińskiej armii - oficjalnie nie jest to Federacja Rosyjska, tylko separatyści. Natomiast wszyscy separatyści Donbasu podzielają podobne wartości ideologiczne, które często są tożsame z rosyjskimi 
wartościami polityczno-ideologicznymi. Wskazuje to na hybrydowy charakter konfliktu - bez oficjalnego wypowiedzenia wojny oraz bez określonego, domniemanego przeciwnika. Hybrydowość oznacza mieszanie się różnych elementów (Gruszczak, 2011, s. 11). W odniesieniu do konfliktu w Donbasie oznacza to, że na charakter wojny toczonej tam składa się wiele czynników. Charakteryzuje się ona wieloma wskaźnikami, a głównym z nich jest nieokreślony przeciwnik.

„Współczesne zagrożenia i konflikty różnią się znacznie od tych, jakie występowały nawet $\mathrm{w}$ nieodległej przeszłości. Dzisiaj mamy do czynienia z „wojnami postindustrialnymi”, które toczą się na wielu płaszczyznach, między innymi na płaszczyźnie mediów, organizacji międzynarodowych, szczytów politycznych. Sama wojna konwencjonalna jest jedną z wielu części wojny hybrydowej" (Asymetria i hybrydowość - stare armie wobec nowych konfliktów, s. 5).

Także wojnę hybrydową określa się jako „wojnę trzeciej fali”, „wojnę bez okupacji”, „wojnę post-technologiczną” (Antczak-Barzan, 2016, s. 19).

Konflikt w Donbasie nie jest wyjątkiem w tych definicjach. „Armie masowe, niezawodne, w obecnych konfliktach sprawdzają się coraz gorzej. Istnieje potrzeba wcielenia dużo bardziej elastycznych metod walki i środków, pozwalających przeciwstawić się nowym przeciwnikom, o innym stopniu zorganizowania niż klasyczne wojsko" (Asymetria i hybrydowość - stare armie wobec nowych konfliktów, s. 5). W Donbasie w latach 2014-2015 miały miejsce starcia różnego charakteru - tak z nieregularnymi jednostkami w miastach, jak i z regularnymi jednostkami w polu.

Warto stwierdzić, że na Ukrainie toczy się wojna hybrydowa, która składa się z:

- $\quad$ wojny konwencjonalnej (terytorialny zasięg - Donbas);

- $\quad$ wojny informacyjnej (zasięg - cały świat);

- $\quad$ wojny gospodarczej (zasięg - podstawowe obszary gospodarki Ukrainy, wzajemne sankcje gospodarcze Rosji oraz Zachodu);

- wojny organizacyjnej (zasięg - Ukraina, teoretycznie niektóre rządy europejskie, sposób - korupcja, szantaż, szpiegostwo);

- $\quad$ wojny chronologicznej (zasięg - Ukraina, w szczególności Donbas oraz Krym, udowodnienie przez historię, że Ukraina jako państwo nie istnieje, że Ukraińcy są niewolnikami z natury, etc.);

- $\quad$ wojny duchowej, mentalnej (terror psychologiczny, upokorzenie godności ludzkiej w celu sparaliżowania jakichkolwiek 
działań). Wojna duchowa polega także na narzuceniu wykrzywionych wartości, niszczeniu motywacji do życia, wykrzywieniu pojmowania procesów naturalnych, etc. Należy zauważyć, że ten poziom wojny podlega dalszej dyskusji naukowej.

\section{PrZYWÓDCY RUCHU SEPARATYSTYCZNEGO NA UKRAINIE W 2014 ROKU}

PRZYWÓDCY SEPARATYZMU W MARCU 2014 R. ORAZ W POPRZEDNIM CZASIE (2004 ROK) byli w większości przedstawicielami Partii Regionów, dla których Donbas był rzekomą „ojczyzną polityczną”. Już później, w lutym 2014 r. wyklarowali się inni przedstawiciele ruchu separatystycznego - tak zwani ludowi burmistrzowie (Pawieł Gubariew w Doniecku), prezesi miast (Słowiańsk, Kramatorsk, Ługańsk, Siewierodonieck), którzy wystąpili po stronie separatystów ${ }^{4}$. Puszylin Denis, Aleksandr Borodaj (przewodniczący „DNR”), Igor Girkin (dowodzący tak zwanymi woskami „DNR”), Igor Biezler (komendant miasta Gorłówka), Boris Litwinow (współprzewodniczący organizacji „Donieckiej Republiki Autonomicznej”), Zdryluk Siergej (zastępca przewodniczącego wojsk „DNR”), Ponomariow Wiaczesław (ludowy prezydent miasta Słowiańsk), Mozgowoj Ołeksij (przewodniczący oddziału zbrojnego „Prizrak”), Andriej Purgin (organizacja „Doniecka Republika”) oraz inni. Warto zaznaczyć, że wielu z nich podtrzymywało więzi polityczne z Rosją, niektórzy z nich służyli w wojsku Ukrainy lub Rosji.

Ww. działacze przejęli odpowiedzialność za separatystyczne działania oraz akty terrorystyczne na wschodzie Ukrainy w latach 2014-2015. Większość z nich do dziś zajmuje kluczowe stanowiska $\mathrm{w}$ „DNR”oraz „ENR”.

RUCH SEPARATYSTYCZNY W OKRESIE MARZEC-KWIECIEŃ 2014 ROKU. DĄŻENIA POLITYCZNE SEPARATYSTÓW

POWSTANIE MARIONETKOWYCH REPUBLIK „DNR” ORAZ „ENR” STA£O SIĘ HISTORYCZNYM przejawem secesjonizmu na Ukrainie w 2014 r. Separatystyczne twory w Donbasie uznane zostały przez Parlament Ukraiński za organizacje terrorystyczne.

${ }^{4}$ Puszylin Denis, Aleksandr Borodaj (przewodniczący 'DNR'), Igor Girkin (przewodniczący tak zwanymi woskami 'DNR'), Igor Biezler (komendant miasta Gorłówka), Boris Litwinow (współprzewodniczący organizacji „Donieckiej Republiki Autonomicznej”), Zdryluk Siergej (zastępca przewodniczącego wojsck 'DNR'), Ponomariow Wiaczesław (ludowy prezydent miasta Słowiańsk), Mozgowoj Ołeksij (przewodniczący oddziału zbrojnego „Prizrak”), Andriej Purgin (organizacja “Doniecka Republika”) oraz inni.

${ }^{5}$ Doniecka Republika Ludowa oraz Ługańska Republika Ludowa. 
Jednym z przejawów separatyzmu na Ukrainie w sierpniu 2014 r. był ukryty atak ze strony Federacji Rosyjskiej (jeden z przykładów tzw. Kociół Iłowajski, 10 sierpnia - 3 września 2014 r.), jej kontrola oraz koordynacja ww. republik marionetkowych, kontrola granicy państwowej, etc.

Nasilenie ruchu separatystycznego było spowodowane następującymi czynnikami:

- $\quad$ upadek reżimu byłego prezydenta Ukrainy Wiktora Janukowycza oraz rządzącej Partii Regionów;

- $\quad$ pewne niezdecydowanie nowego rządu Ołeksandra Turczynowa, które klarownie przejawiło się podczas aneksji przez Rosję Krymu w marcu 2014 r.;

- lojalność jednostek milicji w stosunku do separatystów;

- zniszczenie spraw gospodarczych oraz karnych (innymi słowy „zacieranie śladów”);

- ciągłe powtarzanie przez elity Donbasu o wyjątkowości ludzi Doniecka oraz Ługańska.

Zgodnie z prawem w 2014 r. zjawisko separatyzmu na Ukrainie zostało skierowane przy wsparciu lokalnych elit. Na przykład głosowanie przez Ługańskie prezydium w sprawie zatrzymania Operacji Antyterrorystycznej na wschodzie Ukrainy. Niezgodnie z prawem Ukrainy separatyzm ujawnił się w zamieszkach wspieranych przez grupy kryminalne oraz wyżej wymienionych działaczy. Później, w kwietniu 2014 r. separatyzm nabył formę wojskowych przejęć urzędów lokalnych oraz administracji obwodowych oraz powiatowych.

Zainspirowani sukcesem secesji oraz przyłączenia Krymu do Rosji, separatyści ogłosili wezwanie na 11 maja 2014 r. do referendum w sprawie suwerenności Donieckiej oraz Ługańskiej Republiki Ludowej. Referendum odbyło się wbrew Konstytucji Ukrainy, a zatem nie może być uznane za legalne.

Pragnienia oraz ideologia separatystów w Donbasie przejawiła się w wymogach możliwości wybrania lokalnych prezesów miast oraz przewodniczących regionalnych administracji. Separatyści wymagali także federalizacji Ukrainy oraz szerszych praw administracyjnych dla Donieckiego oraz Ługańskiego obwodu. Kwestią sporną była także ta dotycząca języka - separatyści wymagali od Kijowa uznanie rosyjskiego za drugi państwowy język dla całej Ukrainy.

W rzeczywistości, w Donbasie doszło do nakłaniania oraz ułatwiania działania separatystom przez lokalne administracje oraz niektórych liderów Partii Regionów. Ponadto, separatyzm w Donbasie 
występował wraz z sabotażem oraz był w pewnym sensie zjawiskiem autonomicznym - sterowanym tylko przez przywódców separatystów.

\section{Podsumowanie}

Antyterrorystyczna operacja w Donbasie wciąż trwa. Ewidentnie dążenia separatystów, wspieranych Federacją Rosyjską, nie były do końca spełnione. Porozumienia mińskie, podpisane na Białorusi 12 lutego 2015 r. nadal są bardzo niestabilne. Ukraina wciąż jest przygotowana do wojny hybrydowej, a separatyści nadal wysuwają roszczenia o przyjęciu innych obwodów - sytuacja jest niestabilna zwłaszcza w obwodach Charkowskim oraz Odeskim. Południe obwodu Zaporoskiego jest wciąż narażone na przejęcie przez separatystów ze względu na swoje położenie geopolityczne. Części obwodów Donieckiego oraz Ługańskiego, które kontrolowane rządem Ukrainy separatyści uważają za „terytoria okupowane”.

Po opisaniu oraz zweryfikowaniu przyczyn procesów secesji w południowo-wschodniej Ukrainie oraz Donbasie można twierdzić, że podział Ukrainy w wyżej opisanych podłożach nie występuje pomiędzy regionami Ukrainy. Pomimo, iż ruch separatystyczny był rozpowszechniony we wschodnich regionach Ukrainy (zwłaszcza w Odeskim, Zaporoskim, Charkowskim, Donieckim oraz Ługańskim), do działań wojennych doszło tylko w dwóch obwodach (Donieckim oraz Ługańskim). Stąd wynika, że podział Ukrainy na wschód/zachód jest sztuczny, ponieważ separatyści skutecznie byli wspomagani przez społeczność lokalną tylko obwodach Donieckim oraz Ługańskim.

Przyczyn oraz przesłanek ruchu separatystycznego na Ukrainie w 2014 r. warto dopatrywać się w wielu podłożach. Najbardziej znaczące są tutaj podłoże polityczne, etniczne, językowe oraz cywilizacyjne. W wydarzeniach, które miały miejsce na Ukrainie od wiosny 2014 r. i trwają do momentu napisania artykułu, podłoże polityczne odegrało kluczową rolę. Decydujące również są podłoża etniczne, ekonomiczne oraz językowe. Jednak nie da się całkiem wykluczyć znaczenia podłoża cywilizacyjnego.

Wojna hybrydowa w Donbasie może być postrzegana nie tylko jako konflikt polityczny oraz wojskowy, ale również jako cywilizacyjna konfrontacja, jako zderzenie cywilizacyjne wbrew temu, że według Samuela Huntingtona, tak Ukraina, jak i Federacja Rosyjska należą do jednej - prawosławnej cywilizacji. W podobnym nurcie należy nadal analizować to społeczno-polityczne oraz cywilizacyjne zjawisko w kolejnych badaniach. 


\section{BibLIOGRAFIA}

Antczak-Barzan A., Śliwa Z., Zaniewski R. (2016), Wojna XXI wieku. Początki wojny „trzeciej fali”, Warszawa.

Clausewitz Carl von. (1958), O Wojnie, Warszawa, Biblioteka Wiedzy Wojskowej.

Encyklopedia Wiedzy Politycznej (2005) pod red. Marka Chamaja, Joanny Marszałek-Kawy, Wojciecha Sokoła, Toruń, Definicja: secesja.

Gruszczak A. (2011), Hybrydowość wspótczesnych wojen - analiza krytyczna. Praca zbiorowa pod red. Sokała W. i Zapała B., Asymetria i Hybrydowość - stare armie wobec nowych konfliktów, Warszawa.

Huntington S. (2002), Zderzenie cywilizacji i tworzenia nowego ładu światowego, Londyn.: „The Free Press”.

Mały Stownik Politologii (2007), pod red. Stefana Opary i zespołu, Toruń, Definicja: separatyzm.

Mały Stownik Polityki (1998) pod red. Teresy Malmon, Teresy Opoki, Radom, Definicja: secesja.

Pastor Ł., 3 mld dolarów w budżecie na budowę mostu Rosja - Krym, Rynek Kolejowy, http://www.rynek-kolejowy.pl/wiadomosci/3-mld-dolarow-wbudzecie-na-budowe-mostu-rosja--krym-75930.html, 29.03.2016.

Studenna-Skrukwa M. (2014), Ukraiński Donbas. Oblicza tożsamości regionalnej, Wydawnictwo Nauka i Innowacje, Poznań.

Unian, У Луганську оголосили про створення «ЛНР», Царьов заговорив про «повноцінну Новоросію» - 3MI, http://www.unian.ua/politics/917156-u-lugansku-ogolosili-pro-stvorennya-lnr-tsarov-zagovoriv-pro-povno tsinnu-novorosiyu-zmi.html, 27.03.2016.

Workingman's death, Lotus Film GmbH/Vienna and Quinte Film/Freiburg with arte G.E.I.E., 2005, http://www.workingmansdeath.at/about_ en.html, 25.06.2015.

Дзеркало Тижня, Посольство США кваліфікувало дї сепаратистів на сході України як тероризм, http://dt.ua/POLITICS/posolstvo-sshakvalifikuvalo-diyi-separatistiv-na-shodi-ukrayini-yak-terorizm-142477_. html, 25.03.2016.

ЕФремов Александр Сергеевич, Liga.net, http://file.liga.net/person/365-aleksandr-efremov.html, 8.03.2016.

Зануда А., Дороши С., Розкриття архівів: як після Голодомору на Донбас переселяли росіян, ВВС Україна, http://www.bbc.com/ukrainian/society/2015/06/150522_holodomor_donbass_russia_az, 30.03.2016.

Луганский Областной Совет, Об укреплении организационной структуры местной власти в Луганской области, http://web. 
archive.org/web/20150301143805/http://oblrada.lg.ua/node/2159, 30.03.2016.

Президент России, Договор между Российской Федерацией $и$ Республикой Крым о принятии в Российскую Федерацию Республики Крым и образовании в составе Российской Федерации новых субъектов 18.03.2014, http://www.kremlin.ru/news/20605, 25.03.2016. Президент України. Офіційне інтернет-представництво, Лист в.о. Президента України Олександра Турчинова до Міністра юстиції України Павла Петренка 19.05.2014, http://www.president.gov.ua/ news/30410.html, 30.03.2016.

РиаНовости, История Украинских Референдумов 15.03.2014, http:// rian.com.ua/analytics/20140315/341118157.html, 30.03.2016.

Смолій В. А. (2012), Повсякденне життя на підприємствах $i$ новобудовах, ред., Київ.

Українська Правда, РНБО розпочинае масштабну АТО із залученням Збройних Сил - Турчинов, http://www.pravda.com.ua/ news/2014/04/13/7022274/, 30.03.2016.

Украӥнський Тиждень, Казанський: на «місцевому референдумі» 1994 року 8о\% жителів Донбасу голосували за федералізацію, http://tyzhden.ua/News/126090, 28.03. 2016.

\section{SUMMARY}

In this paper was taken an attempt to research the causes of separatism in the Donbass based on a multi-faceted inquiry. Donbass has always been a key region in Ukraine. In many cases here were decided the political and economic destiny of the state. This region is the most socially and economically diversified. Donbass is a place of the most dangerous working conditions and the enormous social inequalities in Ukraine.

In 2014 after the events at the Euromaidan Donbass was a field of fighting between the Ukrainian government and Russian-backed separatists. The issue of separatism in Ukraine remains unresolved.

\section{Nota o Autorze}

Andrii Gladii [andrii.gladii@amu.edu.pl] - doktorant na Wydziale Nauk Politycznych i Dziennikarstwa UAM. Jego zainteresowania naukowe obejmują ekonomiczne oraz społeczne skutki globalizacji, 
historię stosunków międzynarodowych, globalnej gospodarki opartej na wiedzy, bezpieczeństwo telekomunikacyjne, teorię wojny hybrydowej. Obecnie pod kierownictwem profesora Zdzisława Puśleckiego prowadzi badania nad charakterem konfliktu zbrojnego w ukraińskim Donbasie w latach 2014/15. Posługuje się językami angielskim, rosyjskim oraz ukraińskim. 
